\title{
Approval Plan Purchasing in Perspective
}

\begin{abstract}
Approval plan purchasing is related to library goals of comprehensiveness, pointing out the interrelated pressures of the university system which have contributed to making this method of purchasing possible and the defensive techniques used to justify it. Suggestions are made concerning future possibilities of continuing to build large collections in individual libraries in the context of present expectations which neglect the all important factor of the use of these collections.
\end{abstract}

\begin{abstract}
A tic current plan punchasting of domesdence of the conditions which have developed in academic libraries during a period of affluence, conditions which have made this method of purchasing possible. In evaluating approval plan purchasing the questions to consider are whether it is economical compared to other methods, and whether it supplies the library with needed materials. Although the purposes behind purchasing books for libraries should be clearly defined on the basis of needs or goals, the goals are often described as "stated educational objectives" and "established program goals,"1 or "maintaining current research strength," ${ }^{2}$ or "most academic librarians today agree. . . ." It has become an assumption without attempts at explanation (indeed, who can explain it) among research librarians that the goals are to acquire everything possible of a "scholarly nature." Even "scholarly" is often defined only nebu-
\end{abstract}

Margaret Dobbyn is social science librarian at Kansas State University library, Manhattan.

480 / lously due to the assumption that everyone knows what scholarly is. Another rationalization is reflected in the attitude that anything in print can be discerned or distorted to have some measure of research value to someone at sometime for some unknown reason which the future alone will disclose. In this way actions and explanations are based on remote possibilities removing the librarian further from the reality of decision-making.

As goals become more difficult to define, needs impossible to assess, and criteria for scholarship deteriorate into being exemplified by what is published or printed, advances in understanding approval plan purchasing are not evident although this simple method of purchasing came about due to stress situations which developed in academic libraries' acquisitions departments. ${ }^{4}$ The most specific cause of this stress was, of course, the rapid increase in book funds which had placed heavy burdens on many acquisition departments. Although staffs had increased somewhat as the book funds had grown, the staff increases were often viewed to be insufficient compared to the book fund in- 
creases. Others attribute the growth of approval plans to the pressures caused by poor business techniques and technical services procedures. ${ }^{5}$ Whatever the causes for the stress, approval plan purchasing of current domestic publications gave promise of relieving this pressure on acquisition departments.

Along with the immediate stress situation, other factors contributing to the increase of funds can be traced to increases in expectations, all stemming from growth of population and affluence. Colleges expanded to include graduate programs and universities expanded to include more and more subject areas of research and graduate programs. Standards of criteria based on numbers of volumes per student and faculty were developed. ${ }^{6}$ University administrations frequently assigned prestige and salary according to research and number of publications, thus creating a climate in which graduates and faculty pressure the library to have everything they might want immediately available in order to publish before they perish. Ironically, the tremendous influx of material in print is partly due to the pressures to publish (along with an available market!) spurred on by an exaggerated reverence toward research, and competition among scholars to get the papers and books into print.

The attitudes of the accrediting agencies have been sympathetic to the goal of supplying scholars with all needed materials. They produced systems of counting numbers of volumes and numbers of subscriptions (and gaps in periodical runs!) for each individual library. In short, these agencies have exerted their own unique pressure on the academic system. ${ }^{7}$

As the various pressures operate throughout the system, the library has become the machine for adding as many volumes and subscriptions to each library as book funds will allow. Initiating orders in such quantities became im- possible for the busy faculty; consequently, the teaching faculty released more and more of the responsibility for selection to the librarian and thereby shifted this burden to another desk. The librarian in turn, as noted above, has generally centered the problem in the acquisitions department.

From the agents' view, a plan to supply books for libraries had to be based on the expectation of broad comprehensive coverage in order to justify a library adopting the approval concept and discontinuing the former procedure of placing bids or scattered orders among many suppliers. The book agent surveying the above conditions in academic libraries in 1966 logically reached the conclusion that he would be able to capture the bulk of the domestic book market and make a profit by capitalizing on the librarian's goals of comprehensiveness, inefficient procedures, and a lowering of criteria toward judgment and selectivity. So he sold his approval plan package to librarians who were also anxious to move the problem onto another desk, thereby eliminating some of the pressures exerted on the acquisitions department. ${ }^{8}$

The approval plan contract, once entered into, needs to be defended because an acquisition program geared to an approval plan can no longer be based on needs or values. Discussions of approval plan purchasing of domestic current publications generally center on the questions of economy, selection of materials, and speed of availability of materials. While some insist that it is an economically efficient way of procuring books, others insist that it is not. ${ }^{9}$ Those who advocate that selection is more valuable with the book in hand, know that very little selection takes place after the books arrive, and that redundancy, duplication, and an increasing rate of obsolescence are evident in the mass of print so purchased. The fact is ignored that the percentage of unscholarly ma- 
terial that is added during the process clutters the catalogs and shelves and is available to the unsuspecting student. ${ }^{10}$ The literature even presents various justifications for turning over the selection of what is needed by the university library to a businessman, whose primary interest in the academic community is profit.

Those who argue that the speed of availability is an important benefit of approval plan purchasing neglect the fact that this is actually not important for the great majority of books so purchased. Then too, after receipt many volumes are held up for cataloging and processing, negating in most instances the supposed value of speedy receipt.

As economy and speed become the focal points on which to judge approval plan purchasing, the assumption that every academic library needs all of this material is difficult to bring to the forefront and relate to goals, unless, of course, the goals of academic libraries have become truly broad, comprehensive coverage insofar as funds will permit with a deterioration of criteria on scholarship. In other words, the goals seem to have become, in reality, "add volumes" and hope that if enough volumes are added, broad, comprehensive coverage will result.

It is interesting to view Price's logistics curve as related to the future additions of vast quantities of volumes in libraries. Price states that "In the real world nothing grows and grows until it reaches infinity. Rather, exponential growth eventually reaches some limit, at which the process must slacken and stop before reaching absurdity."11 Hope may exist that something will happen in libraries to prevent the continuous addition of volumes toward absurdity. ${ }^{12}$
Leveling off may occur, but for a time the logistics curve will show signs of fluctuation due to efforts to preserve the status quo. Indications are that recent decreases in funds may have already affected the curve..$^{13}$ If Mason is correct in regard to economies, attitudes toward approval plan purchasing will change as librarians begin to experience less affluence. ${ }^{14}$ Perhaps then we can get down to the business of examining more intelligently Urquhart's first law: The library exists to meet the needs of the user as economically as possible, and find more economical ways to serve the scholar. ${ }^{15}$

It is well known that problems proliferate as college libraries become research libraries. The undergraduate library's needs can be more explicitly defined and provided for. ${ }^{16}$ Suggestions are available for alternate systems of providing research materials but they will be difficult to initiate due to the present system of expectations which has been created. Not to be overlooked is the competition which exists between libraries, and the difficulty of organizing and implementing alternative patterns of organization and service. ${ }^{17}$

In the meantime, while we wait for changes in values, attitudes, and behavior in order to effect institutional changes, ${ }^{18}$ approval plans will continue to be a means of purchasing books for libraries; library volume counts will continue to escalate even though 50 to 75 percent of the books so purchased will be little or never used items. ${ }^{19}$ Approval plan purchasing is a simple, easy, expensive method used by some acquisitions departments to purchase materials, many of which prove to be unnecessary and thus create a drain on other aspects of library operations.

\section{REFERENCES}

1. H. William Axford, "The Economics of a Domestic Approval Plan," CRL 32:368, 370 (Sept. 1971).
2. E. M. Grieder, "Letters to the Editor," CRL 31:344 (Sept. 1970).

3. Jasper G. Schad, Ibid., p. 346 . While Schad 
states that "Most academic librarians agree, ... thirty acquisitions librarians at an Institute on Acquisitions Procedures in Academic Libraries in San Diego, Aug./Sept. 1969 , from thirty different libraries throughout the country did not have acquisitions policies and could reach no agreement on how to set up such an animal. While one staff member recommended "Collection Development Policies" another staff member discredited the idea. One participant stated that the only selection policy evident in his library was reflected in the distribution of funds, while another admitted that since funds were no longer assigned to departments in his library, he "just spent it" as requests came in. Others were more or less silent about their practices, presumably in an effort to gain some guidance toward more meaningful procedures of expenditures. No guidance was given and no consensus arrived at except, "It depends on your library," which became a standard Institute quote.

4. Carol Schaafsman, "Reviews," Library Resources \& Technical Services 15:557-58 (Fall 1971). Schaafsman reviews Advances in Understanding Approval and Gathering Plans in Academic Libraries, edited by Peter Spyers-Duran and Daniel Gore. Kalamazoo, Michigan: Western Michigan University, 1970, in which she indicates that there are more prejudices than understandings.

5. Much of the information used to summarize the present state of the art in this paper can be found in detail in the literature and needs no repetition here. For more information concerning these statements see: (in chronological order). Perry D. Morrison, "A Symposium on Approval Order Plans and the Book Selection Responsibilities of Librarians," with reactions by LeRoy C. Merritt, Joseph P. Browne, Stanley A. Shepard, Library Resources \& Technical Services 12:133-45 (Spring 1968). Ian W. Thom, "Some Administrative Aspects of Blanket Ordering," Library Resources \& Technical Services 13:338-46 (Summer 1969). Norman Dudley, "The Blanket Order," Library Trends 18:318-27 (January 1970). Roscoe Rouse, "Automation Stops Here: A Case for Man-Made Book Collections," CRL 31:147-54 (May 1970). Marion Wilden-Hart, "The Long-Term Effects of Approval Plans," Library Resources \& Technical Services 14:400-06 (Summer 1970 ). "Letters to the Editor," Comments and Rejoinders to Roscoe Rouse, by Grieder, Rebuldela, Schad, Schnaitter, CRL
31:341-48 (Sept. 1970). Colin Steele, "Blanket Orders and the Bibliographer in the Large Research Library," Journal of Librarianship 2:272-80 (Oct. 1970). Axford, "Economics of," p. 368-75.

6. While continuing attention is on standards for evaluating libraries (see Signe Otterson, "A Bibliography on Standards for Evaluating Libraries," CRL 32:127-44 (March 1971)), the National Advisory Commission on Libraries in 1968 found it impossible to evaluate existing standards adopted by the American Library Association which are based on numbers of volumes, and they also point out that "sweeping generalizations with respect to user needs are likely to be misleading through incompleteness and inaccuracy." See the Report of the National Advisory Commission on Libraries, "Library Services for the Nation's Needs: Toward Fulfillment of a National Policy, October 1968," in ALA Bulletin 63:74, 72 (Jan, 1969).

7. It is presently a matter of fact that the university community has available to it on request through interlibrary loan facilities much more than is presently in the individual library locally. The complete list of holdings of all of the libraries from which any library may request material is the actual fact of the number of volumes and titles available. Accrediting agencies must be aware of this. Nevertheless, in May 1971 I was approached to assist in the purchase of $\$ 10,000$ worth of "gaps" in runs of mathematical journals. The government funds had to be spent in a short time and the "gaps" were chosen for purchase to gain "points" (Brownie points?) with the accreditation agency which, as the mathematics professor stated, "counts each gap as a point against the department with graduate programs." One issue may be a "gap" or many volumes may be a "gap"! And too, the "gaps" up for purchase represented titles which had just been proven to be little used or never used titles in this library by a use study of mathematical periodicals completed three weeks earlier by this reviewer.

8. If ninety academic libraries were currently participating in one or more of one agent's approval plans in 1968 (see Morrison, "Symposium on Approval"), it might be estimated that sales amounted to over $\$ 7,200,000$. What are the facts?

9. Again I refer you to the articles listed in footnote 5. However my figures do not agree with Axford's 7.16 percent average discount. Using a sample of invoice slips 
for science books here, the average discount was determined to be 3.07 percent; and a random sample of social science books gave an average discount of 5.62 percent. The stated percentage rates on the invoice slips did not check out to be mathematically correct. When this was discovered, a call to the agent verified an extra charge of 2 percent for each invoice.

10. On looking through 150 invoice slips for current approval plan purchases in $\mathrm{H}$ to HX category, a sociology professor on this campus remarked that he would estimate about 25 percent of these titles as "junk," and also that he hoped his students did not get hold of any of it. See also Henry Voos, "The Information Explosion; or, Redundancy Reduces the Chargel" 32:7-14 (Jan. 1971).

11. Derek J. DeSolla Price, Little Science Big Science. (New York: Columbia University Press, 1963), p. 20.

12. It is interesting to note that the current Bowker Annual has rounded off volume counts to the millions of volumes since 1964-65.

13. In 1966 it was predicted that upper limits of growth of research libraries were unlikely to be approached during the "fifteen years immediately ahead. . . . All would agree that such growth cannot continue indefinitely. Nevertheless, no clues appear (1966) which adequately suggest an early deceleration of growth. If deceleration occurs, it can hardly be expected before 1980 and perhaps not for many years thereafter." O. C. Dunn, W. F. Seibert, and Janice A. Scheuneman, The Past and Likely Future of 58 Research Libraries, 19511980: A Statistical Study of Growth and Change. Lafayette, Indiana, Purdue University, University Libraries and Audio Visual Center. Second Printing, March 1966 , p. 76.

14. Ellsworth Mason, "The Great Gas Bubble Prick't; or, Computers Revealed-by a Gentleman of Quality," CRL 32:193 (May 1971).
15. D. J. Urquhart, "The Library User and His Needs," Research Into Library Services in Higher Education. London: Society for Research Into Higher Education Ltd., February 1968, p. 2.

16. Virgil F. Massman and David R. Olson, "Book Selection: A National Plan for Small Academic Libraries," CRL 32:271-79 (July 1971). A promising design if cooperation were possible!

17. Many writers come to mind. Pings, Kraft, Rose, Boutry, Voos, Ralston-to name a few. I found the most encouraging and yet the most discouraging to be Mason's "Libraries and Change," PLA Bulletin (May 1971), p. 141-50.

18. Vern M. Pings, "The Library as a Social Agency, Response to Social Change," CRL 31:177 (May 1970).

19. No hard data has been found to prove or disprove these statements, however three years experience in two university libraries in acquisitions and in reference handling approval plan books gives one some insights to accompany review of the literature. Axford's tables ("Economics of," p. 375) could easily be interpreted to indicate that four of the five libraries did not need but onehalf of the material that Library 1 was accumulating. $\mathrm{He}$ gives no indication of how much the material is used or how much of the unacquired 50 percent is missed in Libraries 2 to 5 .

In a library with simple automation procedures which correlate the acquisition of books with circulation records it would not be impossible to actually measure the use, over five or even ten years, of 13,000 volumes received in one year on a domestic approval plan contract. The expense and tedium of such a use study probably do not seem practical in view of signs which indicate that the results will yield evidence of waste and who wants to be shown up as wasteful? Besides, at this time it may be impossible to get a government grant to finance such a study. 